\title{
When the going gets tough, the tough go colder!
}

\author{
Leonard N. Girardi, MD
}

\author{
From the Department of Cardiothoracic Surgery, Weill Cornell Medicine, New York, NY. \\ Disclosures: Author has nothing to disclose with regard to commercial support. \\ Received for publication Sept 27, 2016; accepted for publication Sept 27, 2016. \\ Address for reprints: Leonard N. Girardi, MD, Department of Cardiothoracic Surgery, Weill Cornell Medicine, \\ 525 E 68th St, M404, New York, NY 10065 (E-mail: lngirard@med.cornell.edu). \\ J Thorac Cardiovasc Surg 2017;153:1019-20 \\ $0022-5223 / \$ 36.00$ \\ Copyright (c) 2016 by The American Association for Thoracic Surgery \\ http://dx.doi.org/10.1016/j.jtcvs.2016.09.074
}

In this issue of The Journal of Thoracic and Cardiovascular Surgery, Proventza and colleagues ${ }^{1}$ present data supporting the premise that when using moderate hypothermia $\left(20.1^{\circ} \mathrm{C}-28.0^{\circ} \mathrm{C}\right)$ during surgery on the aortic arch, higher temperatures $\left(24.0^{\circ} \mathrm{C}-28.0^{\circ} \mathrm{C}\right)$ are safe. They examined outcomes and reported no increases in perioperative mortality, permanent neurologic deficit, or permanent renal failure when they performed either hemiarch or total arch reconstruction at these higher temperatures. This group of surgeons is certainly to be commended for continuously and rigorously examining their outcomes and modifying techniques for highly complex aortic reconstructions. As with all studies that provoke thoughtful discussion, however, the devil is in the details. When examining outcomes in these 655 patients, there are patterns to suggest that when the surgery is more difficult because of either complex anatomy or patient comorbidity, even in the most experienced hands, the temperature is decreased! And probably for good reason.

Consistent brain protection during surgery on the arch can be provided across a broad spectrum of systemic temperatures. Proventza and colleagues ${ }^{1}$ used antegrade cerebral perfusion ( $75 \%$ bilateral, $25 \%$ unilateral). The rate of permanent neurologic deficit was not different between low and high moderate hypothermia $(2.1 \%$ vs $2.7 \% ; P=.6)$ and compares favorably with surgery with profound hypothermia $\left(<20^{\circ} \mathrm{C}\right)$, with or without adjuncts such as retrograde cerebral perfusion. ${ }^{2,3}$ Operative mortality $(5.1 \%)$ was also quite good and did not differ with varying temperature strategies $(4.8 \%$ for low vs $5.4 \%$ for high; $P=$.7). The lower temperature group did, however, have a significantly greater percentage of total arch replacements, reoperative sternotomies, and previous coronary bypass operations. When examining the figures showing the "predicted" temperature versus the "actual" temperature during surgery, the reality was that the more complex surgeries went colder. Despite these potential biases, the only difference in perioperative morbidity seen in the colder group was a greater incidence of postoperative respiratory failure and the need for tracheostomy. Although Proventza and colleagues ${ }^{1}$ did a commendable

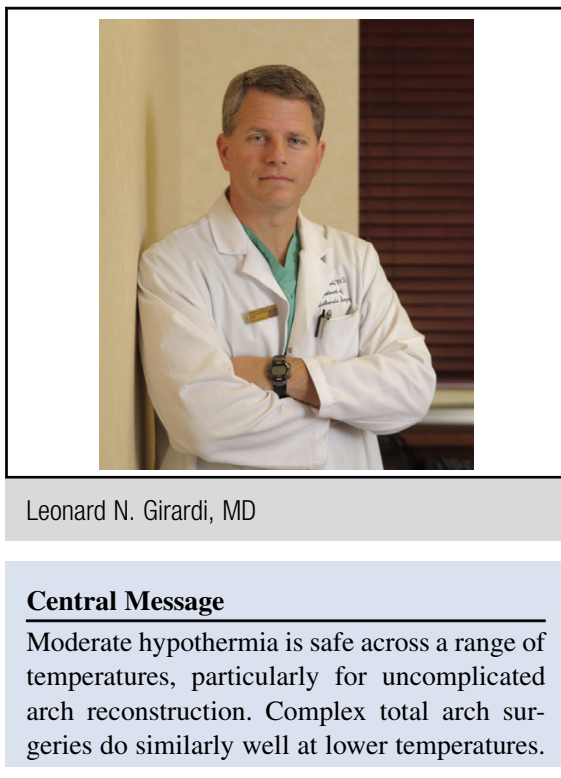

See Article page 1011.

job applying advanced statistical methods to mitigate any bias, it remains challenging to accept that a $3^{\circ} \mathrm{C}$ drop in temperature was the primary driver of respiratory complications. One might instead think that these patients just had more difficult procedures.

Although there were no deleterious effects of low or high moderate hypothermia on the incidence of temporary or permanent renal dysfunction $(12 \%$ vs $13 \% ; P=.69)$, Proventza and colleagues ${ }^{1}$ appropriately caution that "the effect of higher temperature on visceral organ and spinal cord perfusion after aortic arch surgery can be of concern.' This group's extensive experience allowed patients to undergo expeditious arch reconstruction, with a mean total body circulatory arrest time between 22 and 28 minutes. It would be unusual to see significant renal dysfunction with short periods of circulatory arrest, a premise supported by Pacini and associates, ${ }^{4}$ who found similarly low rates of permanent renal injury with moderate hypothermia. The study of Pacini and associates ${ }^{4}$ did, however, report a $22.7 \%$ incidence of hepatic dysfunction in 304 patients. Given the liver's ability to regenerate, it is not surprising that few patients went on to have permanent liver damage. As investigators experiment with higher temperatures in an effort to reduce cardiopulmonary bypass times and the increased transfusion requirements seen with coagulopathy (cardiopulmonary bypass time and packed red blood cell use were both significant predictors of adverse outcomes 
and mortality on multivariate regression analysis), however, they should remain mindful of potential problems below the diaphragm. Warm renal ischemia for longer than 20 minutes is significantly associated with a reduction in glomerular filtration rate (GFR) and the need for permanent hemodialysis. For each minute of warm ischemia, there is a $6 \%$ increase in the risk of acute renal failure and a $4 \%$ increase in the incidence of new-onset permanent dialysis. ${ }^{5}$ These risks are even higher in patients with stage III or higher chronic kidney disease. Yes, arch surgery with moderate hypothermia is safe. It is also apparent, however, that more complicated operations are not less safe because of lower temperatures.

\section{References}

1. Proventza O, Coselli JS, Garcia A, Kashyap S, Avkan S, Simpson KH, et al. Moderate hypothermia at warmer temperatures is safe in elective proximal and total arch surgery: results in 655 patients. J Thorac Cardiovasc Surg. 2017; 153:1011-8.

2. Girardi LN, Shavladze N, Sedrakyan A, Neragi-Miandoab S. Safety and efficacy of retrograde cerebral perfusion as an adjunct for cerebral protection during surgery on the aortic arch. J Thorac Cardiovasc Surg. 2014;148:2927-33.

3. Chau KH, Friedman T, Tranquilli M, Elefteriades JA. Deep hypothermic circulatory arrest effectively preserves neurocognitive function. Ann Thorac Surg. 2013; 96:1553-9.

4. Pacini D, Pantaleo A, Di Marco L, Leone A, Barberio G, Murana G, et al. Visceral organ protection in aortic arch surgery: safety of moderate hypothermia. Eur J Cardiothorac Surg. 2014;46:438-43.

5. Thompson RH, Frank I, Lohse CM, Saad IR, Fergany A, Zincke H, et al. The impact of ischemia time during open nephron sparing surgery on solitary kidneys: a multi-institutional study. J Urol. 2007;177:471-6.

Access to The Journal of Thoracic and Cardiovascular Surgery Online is reserved for print subscribers!

Full-text access to The Journal of Thoracic and Cardiovascular Surgery Online is available for all print subscribers. To activate your individual online subscription, please visit The Journal of Thoracic and Cardiovascular Surgery Online, point your browser to http://www.mosby.com/jtcvs, follow the prompts to activate your online access, and follow the instructions. To activate your account, you will need your subscriber account number, which you can find on your mailing label (note: the number of digits in your subscriber account number varies from 6 to 10 ). See the example below in which the subscriber account number has been circled:

\section{Sample mailing label}

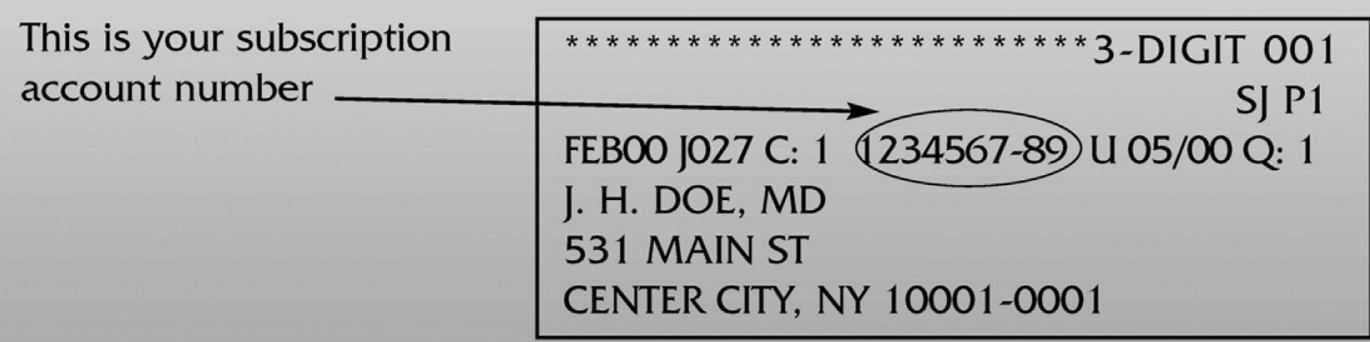

Personal subscriptions to The Journal of Thoracic and Cardiovascular Surgery Online are for individual use only and may not be transferred. Use of The Journal of Thoracic and Cardiovascular Surgery Online is subject to agreement to the terms and conditions as indicated online. 